\title{
Adsorption of Organic Pollutants from Cold Meat Industry Wastewater by Electrochemical Coagulation: Application of Artificial Neural Networks
}

\author{
Jorge del Real-Olvera 1,*(D), Juan Morales-Rivera ${ }^{2}$ (D), Ana Patricia González-López ${ }^{1}$, \\ Belkis Sulbarán-Rangel ${ }^{2}$ ad and Virgilio Zúñiga-Grajeda ${ }^{2, * \mathbb{D}}$ \\ 1 Environmental Technology, Center of Research and Assistance in Technology and Design of the State of \\ Jalisco, Normalistas 800, Guadalajara 44270, Mexico; anapatricia.g123@gmail.com \\ 2 School of Engineering and Technological Innovation, University of Guadalajara, Tonalá 45425, Mexico; \\ juan.morales9853@academicos.udg.mx (J.M.-R.); belkis.sulbaran@academicos.udg.mx (B.S.-R.) \\ * Correspondence: jdelreal@ciatej.mx (J.d.R.-O.); virgilio.zuniga@academicos.udg.mx (V.Z.-G.); \\ Tel.: +52-133-3345-5200 (ext. 2129) (J.d.R.-O.)
}

Received: 25 September 2020; Accepted: 27 October 2020; Published: 29 October 2020

\begin{abstract}
The cold meat industry is considered to be one of the main sources of organic pollutants in the wastewater of the meat sector due to the complex mixture of protein, fats, and dyes present. This study describes electrochemical coagulation (EC) treatment for the adsorption of organic pollutants reported in cold meat industry wastewater, and an artificial neural network (ANN) was employed to model the adsorption of chemical oxygen demand (COD). To depict the adsorption process, the parameters analyzed were current density $\left(2-6 \mathrm{~mA} \mathrm{~cm}^{-2}\right)$, initial $\mathrm{pH}(5-9)$, temperature (288-308 K), and EC time (0-180 $\mathrm{min})$. The experimental results were fit to the Langmuir and Freundlich isotherm equations, while the modeling of the adsorption kinetics was evaluated by means of pseudo-first and pseudo-second-order rate laws. The data reveal that current density is the main control parameter in EC treatment, and $60 \mathrm{~min}$ are required for an effective adsorption process. The maximum removal of COD was $2875 \mathrm{mg} \mathrm{L}^{-1}(82 \%)$ when the following conditions were employed: $\mathrm{pH}=7$, current density $=6 \mathrm{~mA} \mathrm{~cm}^{-2}$, and temperature of $298 \mathrm{~K}$. Experimental results obey second-order kinetics with values of the constant in the range of $1.176 \times 10^{-5} \leq k_{2}(\mathrm{mg}$ COD adsorbed/g-Al.min) $\leq 1.284 \times 10^{-5}$. The ANN applied in this research established that better COD removal, $3262.70 \mathrm{mg} \mathrm{L}^{-1}(93.22 \%)$ with $\mathrm{R}^{2}=0.98$, was found using the following conditions: EC time of $30.22 \mathrm{~min}$, initial $\mathrm{pH}=7.80$, and current density $=6 \mathrm{~mA} \mathrm{~cm}^{-2}$. The maximum adsorption capacity of $621.11 \mathrm{mg} \mathrm{g}^{-1}$ indicates a notable affinity between the organic pollutants and coagulant metallic ions.
\end{abstract}

Keywords: electrocoagulation; artificial neural network; wastewater treatment; cold meat industry

\section{Introduction}

In the literature, it has been generally recognized that the physicochemical characteristics of the wastewaters from the cold meat industry and from slaughterhouses are very similar. In both cases, the volume of effluent generated is between 5 and $8 \mathrm{~m}^{3}$ per ton of meat processed. Because only a small number of scientific reports are related directly to cold meat industry wastewater, generally, the characteristics of slaughterhouse wastewater have frequently been employed as a reference [1].

Usually, the effluents generated in meat industries have elevated concentrations of organic compounds such as carbohydrates, color, and high chemical oxygen demand. Nowadays, physical, biological, and chemical treatments have been utilized to depurate wastewater in the cold meat industry [1,2]. Nevertheless, due to the increasing need for meat processes that are more sustainable and more environmentally friendly, diverse scientific studies have been reported where the use of 
various electrochemical treatments is proposed for the adsorption of a great variety of organic pollutants in wastewater from this sector [3].

The more relevant physicochemical characteristics of cold meat industry wastewaters are shown in literature reports. They exhibit a high amount of organic compounds determined as biological oxygen demand (BOD) (1200-3000 $\mathrm{mg} \mathrm{L}^{-1}$ ) and chemical oxygen demand (COD) (2780-6720 $\mathrm{mg} \mathrm{L}^{-1}$ ). Additionally, these effluents include a high content of fats, oils, and greases (FOG) (100-200 mg L $^{-1}$ ), total phosphorus (TP) (15-70 mg L $\left.{ }^{-1}\right)$, total nitrogen (TN) (49-287 $\left.\mathrm{mg} \mathrm{L}^{-1}\right)$, and total suspended solids (TSS) (112-1743 $\left.\mathrm{mg} \mathrm{L}^{-1}\right)$. Moreover, they exhibit intense coloration and high conductivity coming from additives and the dye contents [1-3].

Electrochemistry is part of the chemical sciences that is interested in describing the complicated relationship between chemical and electrical effects [4-6]. Usually, the electrochemical process utilized to treat liquid effluents have been divided into two groups, that essentially depend on the place where the reaction occurs, i.e., directly at the surface of the anode or indirectly inside the effluent through the generation of ions provided by the electrodes. In the first case, because of anodic oxidation in the surface-active part of a solid, the contaminants are initially adsorbed on this area and then transformed through an electron-transfer reaction $[7,8]$. For the indirect process, there is the possibility of generating two strong oxidants like the electrochemical products hydrogen peroxide $\left(\mathrm{H}_{2} \mathrm{O}_{2}\right)$ and hypochlorite $\left(\mathrm{ClO}^{-}\right)$[4,9-12]. Typically, $\mathrm{H}_{2} \mathrm{O}_{2}$ and $\bullet \mathrm{OH}$ are the most widely mentioned oxidants though the reaction between $\bullet \mathrm{OH}$ and $\mathrm{Cl}^{-}$may produce $\mathrm{ClO}^{-}$.

An electrocoagulation cell consists of two or more electrodes, which are immersed in the wastewater. During the process, the anode is dissolved to produce coagulant metallic ions and bubbles of hydrogen and hydroxyl ions simultaneously appear at the cathode. Because of its low cost, aluminum is one of the commonly utilized anode materials in several researches [9-11]. The operation of an EC cell is affected by the conditions of the work imposed. Thus, the more relevant variables that may be mentioned are initial $\mathrm{pH}$, current density, type and concentration of pollutant, agglomerate size, andfloc stability [10-12].

When a current is distributed through the aluminum electrodes, the metal (Al) is oxidized to its cation form $\left(\mathrm{Al}^{3+}\right)$ (Equation (1)). Thus, EC inserts metal cations in situ by employing sacrificial anodes. However, oxygen is also obtained (Equation (2)). The following equations show the standard anode potentials $\left(E_{A}^{0}\right.$, volts $)$, these values imply that when the number is more negative, the reducing agent is stronger $[4,13]$.

$$
\begin{gathered}
\mathrm{Al} \leftrightarrow \mathrm{Al}^{3+}+3 \mathrm{e}^{-} \\
E_{A}^{0}=-1.66 \mathrm{~V} \\
4 \mathrm{OH}^{-} \rightarrow \mathrm{O}_{2}+2 \mathrm{H}_{2} \mathrm{O}+4 \mathrm{e}^{-} \\
E_{A}^{0}=-0.40 \mathrm{~V}
\end{gathered}
$$

The reactions that take place at the cathode are affected by $\mathrm{pH}$. Hydrogen is formed via Equation (3) when the $\mathrm{pH}$ of the system is neutral or alkaline [4,13]:

$$
\begin{gathered}
2 \mathrm{H}_{2} \mathrm{O}+2 \mathrm{e}^{-} \rightarrow 2 \mathrm{OH}^{-}+\mathrm{H}_{2} \\
E_{A}^{0}=-0.83 \mathrm{~V}
\end{gathered}
$$

In contrast, hydrogen is generated via Equation (4) under acidic conditions:

$$
\begin{gathered}
2 \mathrm{H}^{+}+2 \mathrm{e}^{-} \rightarrow \mathrm{H}_{2} \\
E_{A}^{0}=0 \mathrm{~V}
\end{gathered}
$$

At both electrodes, the chemical dissolution of aluminum is explained by Equations (5) and (6), respectively $[4,13]$ :

$$
\begin{gathered}
\mathrm{Al}+3 \mathrm{H}_{2} \mathrm{O} \rightarrow \mathrm{Al}(\mathrm{OH})_{3}+1.5 \mathrm{H}_{2} \\
\mathrm{Al}+4 \mathrm{H}_{2} \mathrm{O}+\mathrm{e}^{-} \rightarrow \mathrm{Al}(\mathrm{OH})_{4}^{-}+2 \mathrm{H}_{2}
\end{gathered}
$$


Electrochemical coagulation (EC) treatment is an electrochemical method, which generates coagulants that are capable of removing suspended solids, colloidal material and metals, as well as other dissolved solids in water and wastewater. The EC process has been used successfully to remove contaminants such as pharmaceutical derivatives, pesticides, and organic pollutant. The dissolution of metal ions in water generates high metal concentration in the solution, to increase over time and causing them to finally precipitate as oxides, capturing to contaminants. Currently, the advantages that are shown by the EC treatment, and due to the low costs of the material used, the EC process is being more widely accepted over other physicochemical processes $[10,11,13]$.

An artificial neural network (ANN) is a computational program composed of units known as neurons, which try to reproduce the biological processing capacity of the human brain [14]. Neurons are connected processors operating in parallel to do a specific task, like modeling the wastewater treatment process [15]. Because many dynamic chemical systems can be represented as a relationship between the observed response and the disturbance that caused it this change, a training algorithm is utilized to adapt the parameters, like bias and weights, at the beginning of the process of modelling through ANN. At the present time, different procedures are proposed for adapting neural networks. Nevertheless, the first algorithm recognized was backpropagation [16]. The authors of this research have reported the use of various metaheuristic techniques to model and optimize the elimination of COD present in wastewater from the cold meat industry [17]. Thus, to complement the previous published information, this document describes the behavior of the adsorption and kinetics in the removal of COD under a greater number of work conditions.

Literature reports that ANN models display the ability to model the EC process when they are utilized for depicting the adsorption of a wide variety of industrial wastewaters like dairy [16], greywater [18], slaughterhouse water [1,19], cold meat industry [17], dyes [20], and among other pollutants [21]. Previous work has shown successful results when using ANN models to find the optimal operational conditions that improve the removal efficiency of wastewater treatment. In a previous investigation of the removal of chromium in wastewater from the metal industry, a removal efficiency of $97 \%$ was obtained. The coefficient of determination of the neural network was $R^{2}=0.9$ [22]. Hasani et al. 2018 proposed an ANN to model a pulse current electrocoagulation-flotation process to remove acid from aqueous media. The efficiency was almost $100 \%$ and $R^{2}=0.999$ [23]. In other investigation combined an ANN with a genetic algorithm to predict the behavior of an electro-oxidation reactor to treat synthetic wastewater prepared with a dye. Their results showed a 95\% removal efficiency with a $\mathrm{R}^{2}=0.91$ [24]. In the report of da Silva Ribeiro, 2019, the operational conditions: current density $18.75 \mathrm{~mA} / \mathrm{cm}^{-2}, \mathrm{pH} \mathrm{4}$, and EC time $90 \mathrm{~min}$ were obtained using an ANN with an $\mathrm{R}^{2}$ of 0.973 to remove boron from aqueous solutions [25]. More recently in 2020, the electrocoagulation process was predicted in the sugarcane bagasse-based distillery industry, obtaining an $83.75 \%$ efficiency and $\mathrm{R}^{2}=0.98$ [26]. All these works focus on the enhancement of wastewater treatment performance, and the variables used were current density, $\mathrm{pH}$, electrocoagulation time, mixing speed, inter-electrode distance, and anode-cathode material, among others.

Artificial neural networks are able to handle complex problems and processes that are difficult to describe or predict. These tools can reproduce cause and effect relationships, which makes them efficient and reliable when modeling non-linear processes such as electrocoagulation for wastewater treatment. The aim of this research is to describe the adsorption efficiency of COD present in cold meat industry wastewater by employing electrochemical coagulation as a treatment and modelling its behavior through artificial neural networks. The ANN is trained via experimental data, with the process variables EC time (0-180 min), initial $\mathrm{pH}$ (5-9), temperature (288-308 K), and current density (2-6 $\left.\mathrm{mA} \mathrm{cm}^{-2}\right)$. By using reliable tools such as artificial neural networks, it is possible to predict the behavior of the electrocoagulation process, which allows designing, planning, and implementing more efficient wastewater treatment efforts. 


\section{Materials and Methods}

\subsection{Electrochemical Monopolar Cell}

The experiments of electrochemical coagulation (EC) were performed in a batch electrolytic cell of glass with jacket and a capacity of $1.5 \mathrm{~L}$ in monopolar configuration (Figure 1). Due to its low cost, aluminum is one of the materials commonly utilized as electrode in several researches [9-11]. The experiments proposed in this investigation were carried out using two aluminum plates (98.57\% Al) (Mingtai, China) as cathode and anode, because to its easy availability and low cost. However, the dissolution of aluminum in the aqueous system, obliges to change the electrodes with some regularity, this replace increase the operative costs. Electrode dimensions were $125 \times 55 \mathrm{~mm}$ with $3 \mathrm{~mm}$ thickness, and the electrode gap was $5 \mathrm{~mm}$, as suggested by the literature [17,27]. The dimensions proposed for this electrolytic cell at the laboratory level must be adjusted appropriately, if it is required to scale the electrolytic system to carry out real treatment operations. The electrodes were connected to a DC power supply (Steren PRL-25) for adjusting and maintaining the current density throughout each experiment. The initial $\mathrm{pH}$ of the wastewater was regulated using a $\mathrm{pH}$ meter (OAKION 510), and the diverse working solutions were adjusted with $\mathrm{NaOH}$ and $\mathrm{HCl}(0.1 \mathrm{M})$ to estimate the effect of the initial $\mathrm{pH}$ on the removal efficiency of pollutants. All chemical reagents utilized were of analytical grade (Merck, Germany). The temperature was controlled using a thermostat (Lauda Alpha RA8).

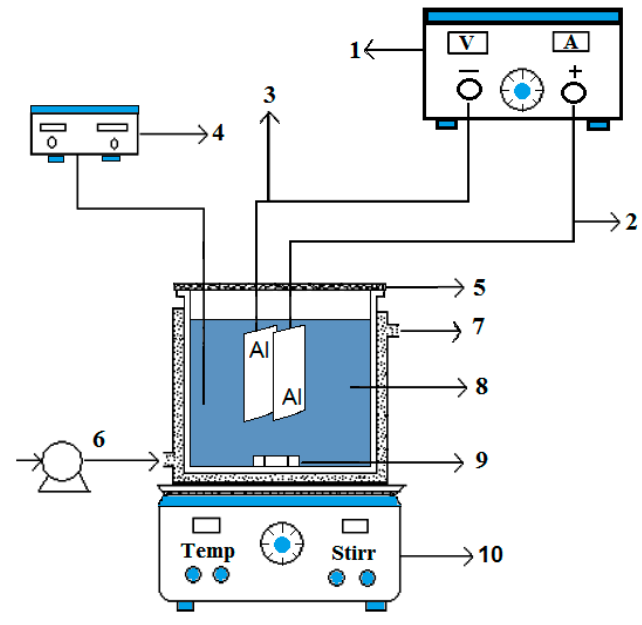

Figure 1. The electrolytic reactor. (1) DC power supply, (2) Anode, (3) Cathode, (4) pH meter, (5) PVC cover, (6) and (7) Inlet and outer jacket, (8) cold meat industry wastewater, (9) Magnetic stirrer bar and (10) Magnetic stirrer.

\subsection{Wastewater Sampling and Analyses}

Samples of effluent were obtained each $24 \mathrm{~h}$ over 5 days from a homogenizer tank of a cold meat plant located in Mexico (16 $3^{\prime} 42.88^{\prime \prime} \mathrm{N}$; $\left.93^{\circ} 22^{\prime} 9.41^{\prime \prime} \mathrm{W}\right)$ to complete a composite sample; this was preserved at $4{ }^{\circ} \mathrm{C}$ until it was utilized in the tests. Physicochemical characterization was carried out in triplicate according to the suggested by Standard Methods for the Examination of Water and Wastewater, these cover over 400 laboratory physicochemical methods for the analysis of important parameters like dissolved solids, metals, free and total chlorine, odor, taste and flavor profile analysis, and total organic carbon [28]. Laboratories worldwide rely on this reference as the trusted source of an adequate, proven methodology for the analysis of water, and wastewater. Here, parameters like BOD, COD, TSS, total phosphorous (TP), fats, oils and greases (FOG), total nitrogen (TN), color, turbidity, and conductivity were evaluated [28]. The species $\mathrm{Na}^{+}, \mathrm{SO}_{4}{ }^{-2}, \mathrm{Cl}^{-}$, and $\mathrm{Ca}^{+2}$ were obtained by ion chromatography with a conductivity detector (Metrohm, model 861) [2]. 


\subsection{Experimental Setup}

In each experiment, $1 \mathrm{~L}$ of cold meat industry wastewater was placed into the electrolytic cell and stirred by a magnetic bar. The experimental design proposed for the tests in the laboratory was a factorial design $\left(3^{3}\right)$ consisting of 27 experimental tests. The process started when the initial $\mathrm{pH}$, current density, and the temperature were adjusted to the required value. To check the reproducibility, $5 \mathrm{~mL}$ samples for triplicate tests were collected at the start of the experiment and every 10 min until achieving $180 \mathrm{~min}$ of operation. To avoid a decrease in the volume of wastewater over time in all experiments, each volume of the sample taken was replaced by raw wastewater. At the end of each experimental run, all of the test samples were allowed to settle for $30 \mathrm{~min}$, and the supernatant sample was accumulated to perform the examination of COD. To avoid any obstruction in the surface of the electrodes and to ensure the reproducibility of the tests, at the beginning of each experiment, the $\mathrm{Al}$-plates were mechanically polished with abrasive paper, submerged completely in $\mathrm{HNO}_{3}(10 \% \mathrm{v} / \mathrm{v})$ for $30 \mathrm{~min}$, and subsequently washed several times with distilled water $[12,16]$.

The sorption capacity of COD at equilibrium and at each time $(t)$ was established by means of Equations (7) and (8), respectively:

$$
\begin{aligned}
& q_{e}\left(m g g^{-1}\right)=\frac{\left(C_{i}-C_{e}\right) V}{W} \\
& q_{t}\left(m g g^{-1}\right)=\frac{\left(C_{i}-C_{t}\right) V}{W}
\end{aligned}
$$

In this case, $q_{e}$ is the adsorption capacity in equilibrium $(e)$ of $\mathrm{COD}\left(\mathrm{mg}\right.$ COD adsorbed $\left.\mathrm{g}^{-1} \mathrm{Al}\right)$; $C_{e}$ and $C_{i}$ are the equilibrium and initial COD $\left(\mathrm{mg} \mathrm{L}^{-1}\right)$, respectively, and $V$ is the volume (L) $[9,19]$. Here, $W$ is the quantity of electrode material dissolved $\left(\mathrm{g} \mathrm{Al}^{3+}\right)$, and this variable was determined utilizing Faraday's law, Equation (9).

$$
W=J \times t \times(M / n) \times(1 / F)
$$

where $J$ is the applied current density $\left(\mathrm{mA} \mathrm{cm}^{-2}\right) ; t$ electrolysis time (s); $M$ is the relative molar mass of the electrode material $\left(\mathrm{g} \mathrm{mol}^{-1}\right) ; n$ is the number of electrons participant in oxidation/reduction reaction, and $F$ is Faraday's constant $\left(96,485.3 \mathrm{C} \mathrm{mol}^{-1}\right)$.

To evaluate the adsorption capacity at each time $\left(q_{t}\right)$, it is necessary to substitute the equilibrium conditions $\left(C_{e}\right)$ by COD at each time $\left(C_{t}\right)$, as displayed in Equation (8). Each test was analyzed in duplicate, and the experimental data represents the mean of the tests with $95 \%$ confidence. The Statgraphics Centurion XVI ${ }^{\circledR}$ program was employed for the statistical studies of the experimental results (Statgraphics.Net, Madrid).

Experimental data were fitted utilizing the Langmuir and Freundlich isotherm equations to describe the equilibrium relations in the experiment as proposed below for different conditions of work [3,29]. Equation (10) was used to estimate the removal efficiency of COD (\%), where $C_{i}$ and $C_{t}$ are the COD concentrations $\left(\mathrm{mg} \mathrm{L}^{-1}\right)$ measured initially and at each respective time [30].

$$
\text { Removal efficiency }(\%)=\frac{\left(C_{i}-C_{t}\right)}{C_{i}} \times 100
$$

\subsection{Development of Theoretical Models}

The result sets for the removal of COD obtained for each batch experiment were employed to obtain theoretical models founded on ANN by utilizing the neural network toolbox of MATLAB R2016a (Mathworks Inc., Natick, MA, USA). In order to measure the contribution of the operative parameters to the adsorption efficiency of COD from cold meat wastewater, three factors were selected: initial $\mathrm{pH}$, current density, and EC time, each with three levels as shown in Table 1. 
Table 1. Independent variables and their levels.

\begin{tabular}{|c|c|c|c|c|}
\hline \multirow[t]{2}{*}{ Factor } & \multirow[t]{2}{*}{ Variable } & \multicolumn{3}{|c|}{$\begin{array}{l}\text { Coded } \\
\text { Variables }\end{array}$} \\
\hline & & -1 & $\mathbf{0}$ & +1 \\
\hline A & Initial pH (P.U) ${ }^{1}$ & 5 & 7 & 9 \\
\hline B & Current density $\left(\mathrm{mA} \mathrm{cm}^{-2}\right)$ & 2 & 4 & 6 \\
\hline C & EC time (min) & 20 & 40 & 60 \\
\hline
\end{tabular}

The range proposed for the theoretical simulation of experimental variables (Table 1), was established according to the original experimental design; moreover, the EC time was proposed taking into account the effective reaction time for chemical adsorption.

In the hidden layers, the neurons were modeled in order to sum up the related bias with the weighted inputs using Equation (11). For the transfer function, the hyperbolic tangent sigmoid was chosen and pure-linear transfer functions were taken for the input and output layers, which were employed to describe the activation function defined by Equation (12).

$$
\begin{gathered}
X_{j}=\sum_{i=1}^{p} y_{i} w_{j i}^{i n}+b_{j}^{i n}, \\
f(x)=\tan \operatorname{sig}(x)=\frac{1-e^{-x}}{1+e^{-x}},
\end{gathered}
$$

In this case, $X_{j}$ is the net input to the node $j$ for the hidden layer, and $y_{i}$ is the input for a neuron $w_{j i}^{i n}$ which represents the weight-related with any input connection from $i$ th to $j$ th neuron inside hidden layer, and $b_{j}^{\text {in }}$ is the bias [31]. All result sets were distributed into three groups: a training group $(70 \%)$; a validation group (15\%), and a test group (15\%) [18]. Figure 2 displays the ANN architecture with input variables, like initial $\mathrm{pH}, \mathrm{EC}$ time $(\mathrm{min})$, and current density $\left(\mathrm{mA} \mathrm{cm}^{-2}\right)$; while the output variable is the adsorption efficiency of COD $(\%)$. Diverse hidden layers were designed to describe the experimental results of this work, like is recommended by literature [16].

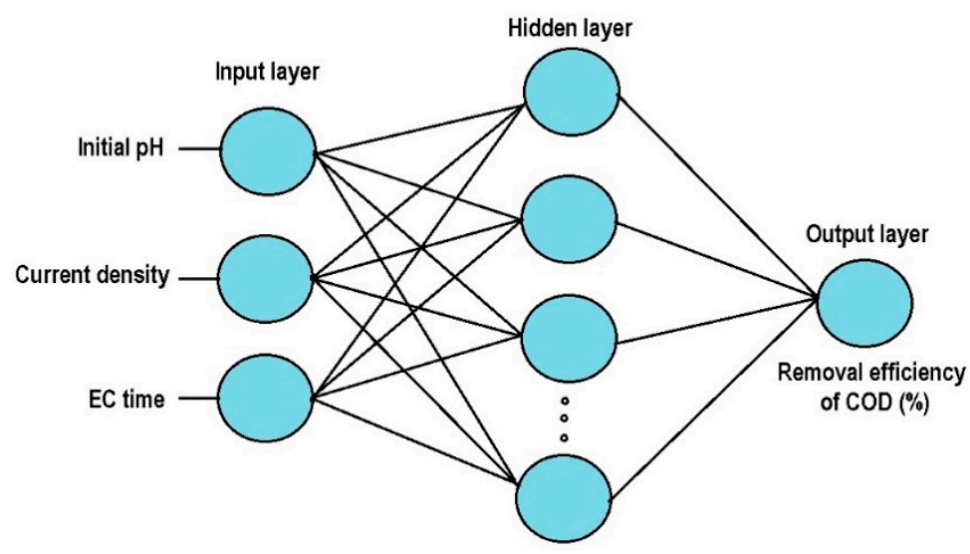

Figure 2. Schematic view of artificial neural network (ANN) model structure.

The experimental data were normalized by applying Equation (13) in the same way as is suggested by the literature [30]. Finally, the total of the neurons in the hidden layer was delimited to a certain number of neurons (from 2 to 10), and these were evaluated using various statistical indices equations like the coefficient of determination $\left(R^{2}\right)$ (Equation (14)), adjusted $R^{2}$ (Equation (15)), and mean squared error (MSE) (Equation (16)). This approach is identical to the method reported in diverse scientific documents [29,31].

$$
X_{\text {norm }}=0.8\left(\frac{x_{i}-x_{\min }}{x_{\max }-x_{\min }}\right)+0.1
$$




$$
\begin{gathered}
R^{2}=1-\frac{\sum_{i=1}^{n}\left(y_{a, i}-y_{p, i}\right)^{2}}{\sum_{i=1}^{n}\left(y_{p, i}-y_{a, a v e}\right)^{2}} \\
\text { Adjusted_R } R^{2}=1-\left[\left(1-R^{2}\right) \times \frac{n-1}{n-k-1}\right] \\
\text { MSE }=\frac{1}{n} \sum_{i=1}^{n}\left(y_{p, i}-y_{a, i}\right)^{2}
\end{gathered}
$$

Here $n$ represents the total number of experimental results, $y_{a, i}$ is the experimental result, $y_{p, i}$ is predicted data, $y_{p, \text { ave }}$ is the average of predicted values, $y_{a, a v e}$ is the average experimental data, and $k$ is the input variable.

\section{Results and Discussion}

\subsection{Characterization of Wastewater}

The physicochemical characteristics of the effluent are shown in Table 2. The organic matter identified as BOD and COD is 2035 and $3500 \mathrm{mg} \mathrm{L}^{-1}$, respectively. The concentration of fats, oils, and grease (FOG) is high, $1114 \mathrm{mg} \mathrm{L}^{-1}$. Moreover, the relationship between the turbidity, color, and TSS is shown. The inclusion of ionic species like calcium, sulfate, sodium, chloride, and potassium is considerable. The presence of these ions in an aquatic system is evidence for the use of several salts and dyes (like potassium phosphate, potassium nitrate, and sodium nitrite) that are handled in the cold meat industry $[1,6,12,17]$. The presence of ionic species as $\mathrm{Cl}^{-}, \mathrm{Na}^{+}, \mathrm{Ca}^{2+}$, and $\mathrm{K}^{+}$ in the wastewater, increases the transfer of energy in the electrolytic cell. This is reflected in a lower electrical consumption at the end of the treatment. Moreover, no chemical salt addition is required to increase the conductivity of system, as suggested in diverse literature reports $[4,6,12]$.

Table 2. Physicochemical characterization of cold meat industry wastewater [2,27].

\begin{tabular}{cccc}
\hline Parameter & Units & Mean Value \pm SD $^{\mathbf{1}}$ & Method \\
\hline pH & $\mathrm{P.U}^{2}$ & $5 \pm 0.2$ & pH-meter \\
Turbidity & $\mathrm{NTU}^{4}$ & $423 \pm 34.2$ & $2130 \mathrm{~B}$ \\
Color & $\mathrm{u} . \mathrm{Pt}^{-C^{3}}$ & $8043 \pm 805$ & $2120 \mathrm{C}$ \\
BOD & $\mathrm{mg} \mathrm{L}^{-1}$ & $2035 \pm 264$ & $5210 \mathrm{~B}$ \\
$\mathrm{COD}$ & $\mathrm{mg} \mathrm{L}^{-1}$ & $3500 \pm 125$ & $5220 \mathrm{D}$ \\
FOG & $\mathrm{mg} \mathrm{L}^{-1}$ & $1114 \pm 220$ & $5520 \mathrm{D}$ \\
TSS & $\mathrm{mg} \mathrm{L}^{-1}$ & $776 \pm 140$ & $2540 \mathrm{D}$ \\
Total phosphorus & $\mathrm{mg} \mathrm{L}^{-1}$ & $25 \pm 1.5$ & $4500-\mathrm{P} \mathrm{E}$ \\
Total nitrogen & $\mathrm{mg} \mathrm{L}^{-1}$ & $135 \pm 7$ & $4500-\mathrm{N} \mathrm{C}$ \\
Alkalinity & $\mathrm{mg} \mathrm{CaCO3} \mathrm{L}^{-1}$ & $300 \pm 17$ & 2320B \\
$\mathrm{Cl}^{-}$ & $\mathrm{mg} \mathrm{L}^{-1}$ & $365.5 \pm 35$ & Ion chromatography \\
$\mathrm{K}^{+}$ & $\mathrm{mg} \mathrm{L}^{-1}$ & $54.4 \pm 0.7$ & Ion chromatography \\
Sulfate & $\mathrm{mg} \mathrm{L}^{-1}$ & $108.9 \pm 1.9$ & Ion chromatography \\
$\mathrm{Ca}^{2+}$ & $\mathrm{mg} \mathrm{L}^{-1}$ & $101.1 \pm 8$ & Ion chromatography \\
$\mathrm{Na}^{+}$ & $\mathrm{mg} \mathrm{L}^{-1}$ & $295.5 \pm 0.45$ & Ion chromatography \\
\hline
\end{tabular}

${ }^{1}$ Standard deviation; ${ }^{2}$ Potential units; ${ }^{3}$ Platinum-Cobalt units; ${ }^{4}$ Nephelometric turbidity units.

\subsection{Adsorption Kinetic Models}

The adsorption kinetic equations frequently described in scientific reports were employed to estimate the adsorption process of COD in the treatment. The adsorption kinetics results found for the adsorption of COD present in cold meat industry wastewater were adjusted to pseudo-first and pseudo-second-order models $[3,29,32]$. The solution to the pseudo-first-order model equation that is 
usually reported in the literature is obtained when the limit conditions from $t=0$ to $t=\mathrm{t}$ and from $q=0$ to $q=q_{t}$ are employed (Equation (17)):

$$
\log \left(q_{e}-q_{t}\right)=\log q_{e}-\frac{k_{1} t}{2.303}
$$

Here $q_{e}$ is the COD equilibrium sorption capacity $\left(\mathrm{mg} \mathrm{g}^{-1}\right), k_{1}$ is the constant of the pseudo-first-order model $\left(\mathrm{min}^{-1}\right)$, and the capacity of adsorption in each time $\left(q_{t}\right)$ is the value of COD removal at time $(t)\left(\mathrm{mg} \mathrm{g}^{-1}\right)$. On the other hand, the linearized equation of pseudo-second-order kinetics takes into account the similar limit conditions (e.g., from $t=0$ to $t=\mathrm{t}$ and from $q=0$ to $q=q_{t}$ ). In this case, $k_{2}$ is the kinetic pseudo-second-order constant $\left(\mathrm{g} \mathrm{mg}^{-1} \mathrm{~h}^{-1}\right)$ (Equation (18)):

$$
\frac{t}{q_{t}}=\frac{1}{k_{2} q_{e}^{2}}+\frac{t}{q_{e}}
$$

The adsorption of COD present in cold meat industry wastewater by EC was monitored with time at three different current densities $\left(2,4\right.$, and $\left.6 \mathrm{~mA} \mathrm{~cm}^{-2}\right)$ for $180 \mathrm{~min}$ employing $\mathrm{pH}=7$ and $298 \mathrm{~K}$, as shown in Figure 3. Here, the removal capacity of COD was studied for an electrolysis time of $180 \mathrm{~min}$ for the test. Nevertheless, the experimental results indicated that the process required just $60 \mathrm{~min}$ before it achieved maximum removal. After obtaining these experimental results, the time proposed for the remaining tests was only $60 \mathrm{~min}$. The first minutes of the adsorption process are crucial, because the highest removal capacity is displayed during this time. This tendency is in accord with behavior analogous to that reported in other manuscripts, which recommend that an electrolysis time between 10-180 $\mathrm{min}$ is required to reach maximum removal for diverse pollutants [32-34].

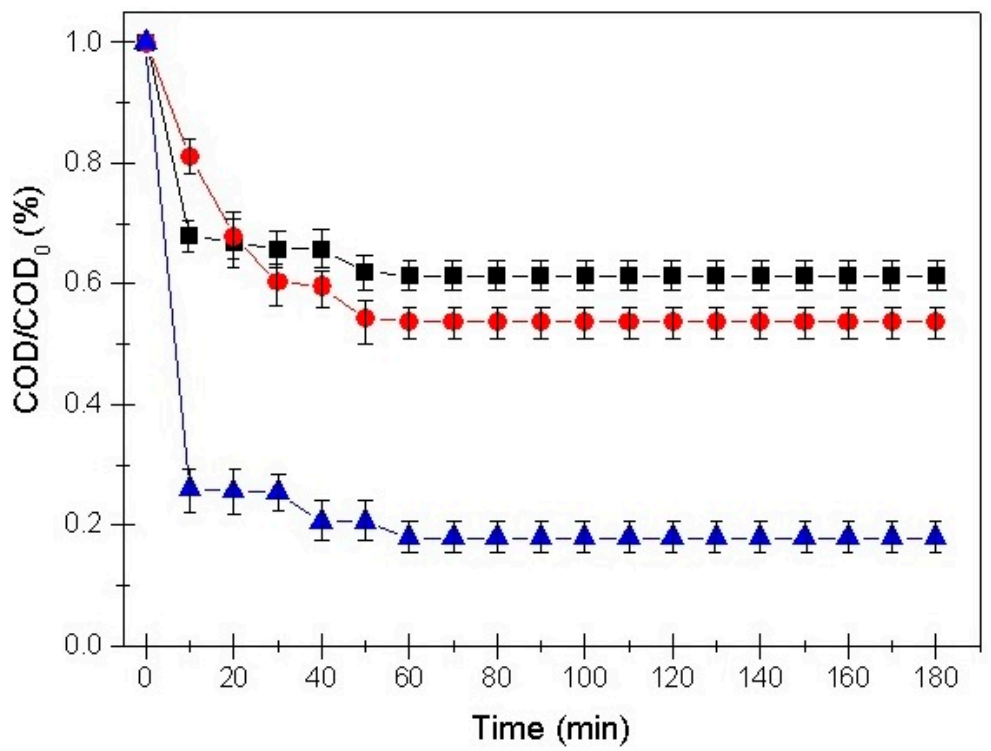

Figure 3. Removal capacity data for chemical oxygen demand (COD) from cold meat industry wastewater as a function of current density using $\mathrm{pH}=7$ and $298 \mathrm{~K}_{\text {with }} 2 \mathrm{mAcm}^{-2}$ (घ); $4 \mathrm{mAcm}^{-2}(\bullet)$, and $6 \mathrm{mAcm}^{-2}(\mathbf{\Lambda})$.

The previous results confirm that the removal process of COD is most important at high current densities values, which implicates the participation of more cation species in the treatment. Appling high current density generates excessive ohmic drop (IR drop) between the electrodes; this increase in voltage indicates greater economic costs. The removal efficiency of COD increased when high current density was applied, implicating important energy consumption. However, the reaction time needed to reach maximum removal capacity is reduced significantly, which can save energy [17]. This rapid removal process can be explained through synergistic effects between physicochemical phenomenon 
generated by EC and COD adsorption, both processes that occur simultaneously. The operational cost is one of the principal concerns when treating wastewater by EC, and it includes the cost of the chemicals used, cost of the dissolved electrodes, and energy consumption. A detailed analysis of the economic cost obtained when the EC method was employed in this research was calculated and reported by this same group of work [17].

The kinetic parameter results found by employing linear regression for both suggested models are shown in Table 3 [1,29,32]. The results presented indicate that although the correlation coefficients $\left(\mathrm{R}^{2}\right)$ in the linear regressions in the two equations are superior to 0.77 for all $\mathrm{pH}$ values proposed, the pseudo-second-order model accurately describes the kinetic performance of the process, which is accord with the results reported in the literature $[1,33]$. The values achieved for the pseudo-second-order kinetic constant $\left(k_{2}\right)$ were between $1.176 \times 10^{-5} \leq k_{2}\left(\mathrm{~g} \mathrm{mg}^{-1} \mathrm{~min}^{-1}\right) \leq 1.284 \times 10^{-5}$ with $\mathrm{R}^{2}$ above 0.83 , this data suggested that the sorption kinetic mechanism was controlled by chemisorption. Comparable performances were described for the removal of COD employing other types of wastewater and EC like treatment [32].

Table 3. Pseudo-first and pseudo-second-order kinetics parameters with different $\mathrm{pH}$.

\begin{tabular}{ccccc}
\hline Model & & pH 5 & pH 7 & pH 9 \\
\hline \multirow{4}{*}{ Pseudo-first-order } & $q_{e}\left(\mathrm{mg} \mathrm{g}^{-1}\right)$ & 2098.9 & 2069.7 & 2423.8 \\
& $k_{1}\left(\mathrm{~min}^{-1}\right)$ & 0.0171 & 0.0197 & 0.0218 \\
& $R^{2}$ & 0.7903 & 0.8037 & 0.7730 \\
Pseudo-second-order & $q_{e}\left(\mathrm{mg} \mathrm{g}^{-1}\right)$ & 726.067 & 703.55 & 1028.92 \\
& $\left.k_{2} \mathrm{gg}^{-1} \mathrm{~min}^{-1}\right)$ & $1.284 \times 10^{-5}$ & $1.238 \times 10^{-5}$ & $1.176 \times 10^{-5}$ \\
& $R^{2}$ & 0.8339 & 0.8749 & 0.8605 \\
\hline
\end{tabular}

\subsection{Evaluation of Adsorption Capacity}

Freundlich and Langmuir isotherm equations were utilized to evaluate the correlations between the experimental results found for diverse operation conditions and the theoretical models. Table 4 shows the data found for both theoretical models. The data corroborate that the Langmuir equation depicts the treatment properly because the $\mathrm{R}^{2}$ value was superior (0.92), indicating that the constants $\left(q_{\max }\right.$ and $\left.K_{L}\right)$ correctly explain the adsorption experimental data. In Table $4, q_{\max }$ is the COD maximum adsorption capacity, which was calculated to be $621.11 \mathrm{mg} \mathrm{g}^{-1}$.

Table 4. Parameters of Langmuir and Freundlich isotherms for COD removal by electrochemical coagulation (EC).

\begin{tabular}{ccccc}
\hline \multicolumn{3}{c}{ Model } \\
\hline \multicolumn{2}{c}{ Freundlich } & \multicolumn{2}{c}{ Langmuir } \\
\hline & $\mathrm{n}$ (dimensionless) & $K_{f}\left(\mathrm{~L} \mathrm{~g}^{-1}\right)$ & $q_{\max }\left(\mathrm{mg} \mathrm{g}^{-1}\right)$ & $K_{L}\left(\mathrm{~L} \mathrm{~g}^{-1}\right)$ \\
$\mathrm{R}^{2}$ & 1.99 & 9.89 & 621.11 & $1.146 \times 10^{-3}$ \\
\hline
\end{tabular}

The Langmuir model suggests that the adsorption of organic pollutants is realized in a monolayer on a group of points with identical adsorption energies independent of the coverage area and with no interaction between adsorbent and adsorbate [29]. Accordingly, this is the more likely process that takes place for COD adsorption by EC treatment, since the Langmuir model best explains the experimental results. Additionally, the graph of $C_{e} / q_{e}$ vs. $C_{e}$ for the removal capacity of COD present in the cold meat industry wastewater (Figure 4) was created to confirm the connection between the experimental results and the data obtained by Langmuir model. 


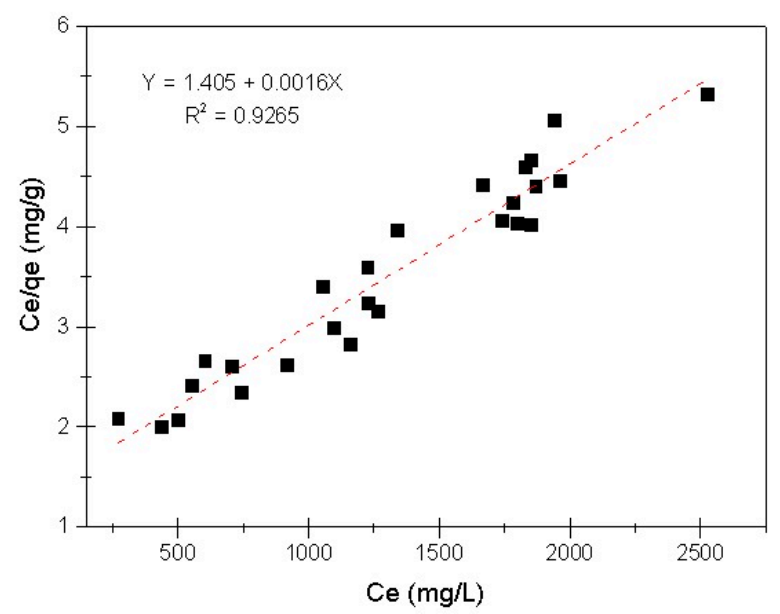

Figure 4. Adjusted linearized Langmuir isotherm model (-) vs. the experimental results ( $\square$ ).

\subsection{Influence of Initial $\mathrm{pH}$ on Removal Efficiency}

$\mathrm{pH}$ is a crucial factor to be taken into account in many electrochemical processes because it affects the efficiency of treatment. $\mathrm{pH}$ has an important effect on the electrode dissolution in the effluent. The $\mathrm{pH}$ has a tendency to increase through time $\mathrm{EC}$, due to permanent insertion of $\bullet \mathrm{OH}$ in the system generated for the pass of electric energy between electrodes. Therefore, describing the direct association between the EC efficiency and $\mathrm{pH}$ is difficult. So, evaluating the initial $\mathrm{pH}$ is generally recommended to define the effect of this parameter on EC [32]. To describe the electrode dissolution in cold meat industry wastewater, the EC process was explored under different initial $\mathrm{pH}$ values (5-9), as indicated in Figure 5.

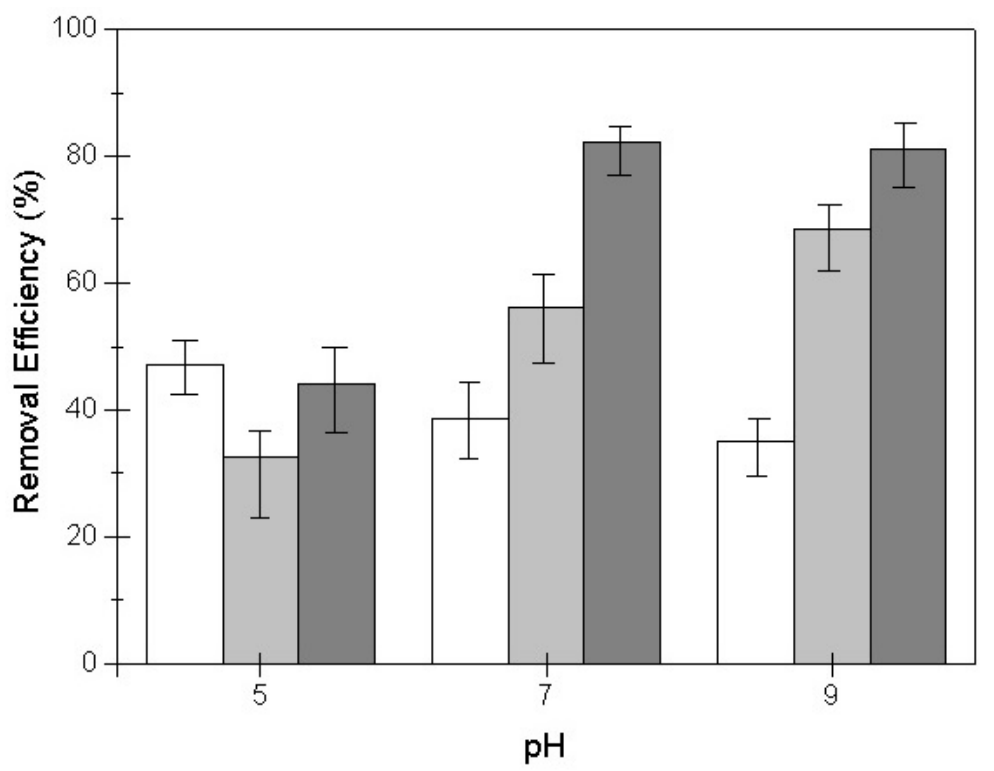

Figure 5. Removal efficiency of COD present in cold meat industry wastewater employing $298 \mathrm{~K}$ and different initial $\mathrm{pH}$ values. The current densities were $2 \mathrm{~mA} \mathrm{~cm}^{-2}(\square), 4 \mathrm{~mA} \mathrm{~cm}^{-2}(\square)$, and $6 \mathrm{~mA} \mathrm{~cm}^{-2}(\square)$.

At low current density $\left(2 \mathrm{~mA} \mathrm{~cm}{ }^{-2}\right)$, the change in $\mathrm{pH}$ value from acid to basic generated a reduction in removal efficiency. However, the difference in the diminution is not significant. The best initial $\mathrm{pH}$ at this current density is $\mathrm{pH}=5$. In agreement with the grater solubility of the cation species when the applied energy is increased in the treatment $\left(4 \mathrm{~mA} \mathrm{~cm}^{-2}\right)$, the removal efficiency is more significant, especially when it raises the $\mathrm{pH}$ value. Here, the adsorption is better when the 
$\mathrm{pH}$ is modified from a low value to a higher value. Finally, when current density value is increased $\left(6 \mathrm{~mA} \mathrm{~cm}^{-2}\right)$, the adsorption shows better performance, because a maximum value was achieved at $\mathrm{pH}=7$. This was the best condition of operation with a removal efficiency of COD $\left(2875 \mathrm{mg} \mathrm{L}^{-1}\right)$ with $82 \%$; however, the residual COD $\left(625 \mathrm{mg} \mathrm{L}^{-1}\right)$ in the aqueous system did not comply with the international standards by effluents water quality $\left(250 \mathrm{mg} \mathrm{L}^{-1}\right)$, for that will be necessary a final treatment to achieve the permissible limits in international standards. In general, the results showed more efficient behavior in a relatively more alkaline or neutral $\mathrm{pH}$ environment [32].

Finally, the $\mathrm{pH}$ of the electrolytic cell regularly increased at the end of all the tests, especially when the electrolytic cell was operated under acidic conditions $(\mathrm{pH}=5)$. The operation conditions with the least variation in $\mathrm{pH}$ from the beginning to the end of the electrolysis time were the basic conditions $(\mathrm{pH}=9)$; however, these basic conditions were not found to have the best pollutant removal efficiency. The results shown seem to confirm that the variation in $\mathrm{pH}$ over electrolysis time does not have an important influence over the final results for adsorption efficiency.

\subsection{Effect of Temperature on the Adsorption Process}

Generally, EC experiments are regularly conducted at room temperature. However, some literature reports have explored the effect of temperature on pollutant removal efficiency employing EC [32]. At elevated temperatures, the generation of metal hydroxides is high due to the faster rate of ionic motion explained by collisions and Brownian movement which destabilize the colloids quickly with high efficiency [33]. Figure 6, depicts the effect of temperature on the adsorption of COD contained in cold meat industry wastewater.

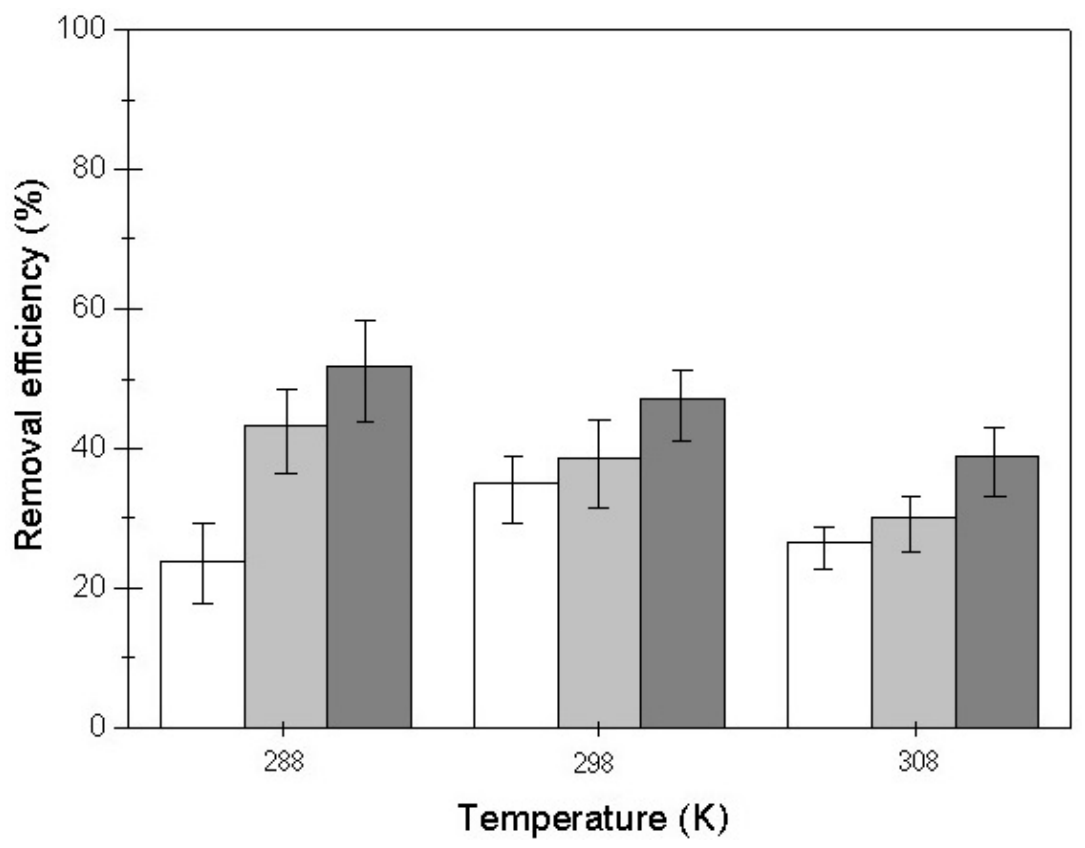

Figure 6. Removal efficiency of COD present in cold meat industry wastewater employing $2 \mathrm{~mA} \mathrm{~cm}^{-2}$ and different temperatures. The initial $\mathrm{pH}$ values were $5(\square), 7(\square)$, and $9(\square)$.

In this study, it was clearly identified that higher temperatures generated negative effects in EC. This behavior can be related to the greater solubility of metal ions when the temperature is increased, which avoids the formation of coagulating floccules that adsorb organic matter. As a result, the capacity to eliminate the filterable precipitates is diminished, leaving behind dissolved substances in the wastewater [32]. Raising the temperature from $288 \mathrm{~K}$ to $308 \mathrm{~K}$ did not significantly change the removal efficiency, but it represented a significant economic cost. To avoid this increase in the economic cost when treating wastewater from the cold meat industry, it is suggested to work the treatment system at room temperature $(288 \mathrm{~K})$. This suggestion agrees with what has been reported in the literature [33]. 


\subsection{Proposed Mechanism for Adsorption}

The analysis of the experimental results suggests that the mechanism involved in the removal of COD by EC is strongly correlated with the value of current density. The predominant mechanism proposed is the adsorption mechanism, since when is increase the current density, improve the adsorption of COD. On the other hand, the charge neutralization mechanism is not relevant, because when a change in $\mathrm{pH}$ value is realized the removal efficiency of COD of wastewater of cold meat industry is not significantly modified. By increasing the current density from 2 to $6 \mathrm{~mA} \mathrm{~cm}{ }^{-2}$, the dissolution of metal is favored and this increases the capture of COD from the aqueous medium.

\subsection{Neural Network Modeling}

In this work, the initial $\mathrm{pH}$, current density, and EC time were the input variables; while removal efficiency of COD was the output variable for modeling cold meat industry wastewater treatment employing the EC process. A total of 102 experiments were performed and utilized to feed the neural network. For ANN modeling, the definition of a correct number of neurons is crucial, because an inferior number of neurons could lead to an overall decrease in the generalizability of the network, and an overpopulation of neurons could establish an over-fitting, produced by memorization of results. Different ANN architectures were tested in this research: $(2,4,6,8$, and 10) hidden layers and statistical coefficients were evaluated (Equations (13)-(15)) and presented in Table 5. It was found that for ANN $(6,8$, and 10) when increasing the number of neurons in the hidden layer, the MSE tended to decrease and coefficients $\mathrm{R}^{2}$ and adjusted $\mathrm{R}^{2}$ developed better performance. On the other hand ANN models ( 2 and 4 ) hidden layer neurons obtained not so significant results as a larger MSE and a lower coefficients $R^{2}$ and adjusted $R^{2}$ this can be explained by the tendency of models with few neurons to reduce the capacity of the network to generalize [16].

Table 5. Performance evaluation in the selection of the ANN.

\begin{tabular}{cccccc}
\hline \multirow{2}{*}{ Parameter } & \multicolumn{5}{c}{ Number of Hidden Layers (Neurons) } \\
\cline { 2 - 6 } & $\mathbf{2}$ & $\mathbf{4}$ & $\mathbf{6}$ & $\mathbf{8}$ & $\mathbf{1 0}$ \\
\hline $\mathrm{R}^{2}$ & 0.9233 & 0.9142 & 0.9576 & 0.9523 & 0.9841 \\
Adjusted $\mathrm{R}^{2}$ & 0.9104 & 0.9134 & 0.9528 & 0.9562 & 0.9734 \\
MSE & 14.77 & 15.63 & 8.41 & 8.22 & 5.77 \\
\hline
\end{tabular}

Regression plots for the optimal ANN model are shown in Figure 7 which reveals a training regression coefficient of 0.980 , validation $(R=0.999)$, test $(R=0.996)$, and test of all data $(R=0.984)$. This indicates that the ANN model proposed in this research correctly describes the behavior of the adsorption process of COD by EC treatment [34]. Employing the ANN model led to better COD removal efficiency of $3262.7 \mathrm{mg} \mathrm{L}^{-1}(93.22 \%)$ under conditions of EC time $=30.22 \mathrm{~min}$, current density $=6 \mathrm{~mA} \mathrm{~cm}^{-2}$, and $\mathrm{pH}=7.8$. These results agree well with reports in the literature when ANN is used to describe the adsorption processes of organic pollutants present in wastewater [32-34]. 

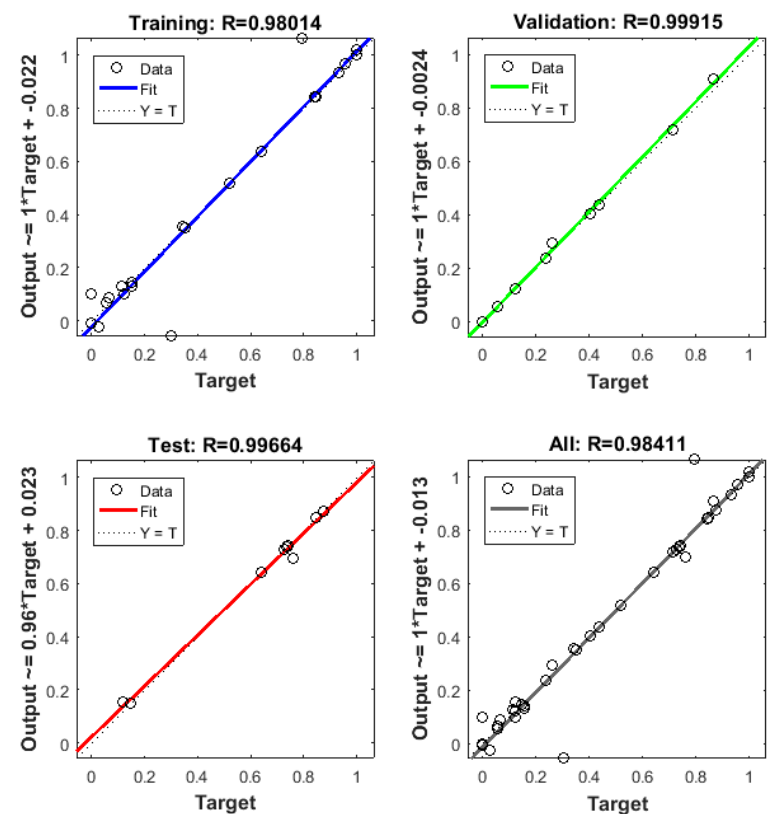

Figure 7. Regression plots of predicted values (-) vs. experimental data (o).

\section{Conclusions}

In this study, employing electrocoagulation (EC) for the adsorption of organic pollutants (COD) present in the cold meat industry wastewater was investigated. The following are the most important findings:

- Subsequent to employing Freundlich and Langmuir equations to fit the results, the linearized Langmuir isotherm equation was identified to be the principal fitting for the COD/EC system.

- The maximum adsorption capacity of COD by EC $\left(q_{\max }\right)$ was found to be $621.11 \mathrm{mg} \mathrm{g}^{-1}$. This value is similar to that obtained when treating diverse types of organic pollutants employing the EC process, which indicates the importance of doing further research into this application.

- The order of relevance for analyzed parameters was current density, initial $\mathrm{pH}$, and contact time. In this case, the current density is the control parameter for COD adsorption by EC, which explained the mechanism through the adsorption rate.

- The pseudo-second-order kinetic equation permitted the accurate prediction of process trends and supported an indispensable comprehension of the treatment for possible upscaling the adsorption process.

- The best performance for ANN was found using 10 neurons in the hidden layer. This achieved a notable representation of all experimental data. With this ANN model, the better COD removal efficiency was $3262.7 \mathrm{mg} \mathrm{L}^{-1}(93.22 \%)$ with $\mathrm{R}^{2}=0.984$ under conditions of current density $=6 \mathrm{~mA} \mathrm{~cm}^{-2}, \mathrm{pH}=7.8, \mathrm{EC}=30.22 \mathrm{~min}$, and temperature $=298 \mathrm{~K}$.

- The predominant mechanism proposed in this system is the adsorption mechanism, since when is increase the current density, improve the adsorption of COD. This no happened when are modified $\mathrm{pH}$ values, and therefore charge neutralization mechanism doesn't seem to be relevant.

- These data indicated good removal efficiency of COD when the EC treatment is utilized, and ANN models are adequate for describing the adsorption behavior.

Author Contributions: In this research, the conceptualization was made by J.d.R.-O. and A.P.G.-L.; writing-original draft preparation J.d.R.-O.; writing-review and editing J.d.R.-O. and V.Z.-G.; experimental methodology by A.P.G.-L.; the simulation and modeling by J.M.-R. and B.S.-R. All authors have read and agreed to the published version of the manuscript.

Funding: This research received no external funding.

Conflicts of Interest: The authors declare no conflict of interest. 


\section{References}

1. Hernández-Ramírez, D.A.; Herrera-López, E.J.; Rivera, A.L.; del Real-Olvera, J. Artificial Neural Network Modeling of Slaughterhouse Wastewater Removal of COD and TSS by Electrocoagulation; Springer International Publishing: Cham, Switzerland, 2014.

2. León-Becerril, E.; García-Camacho, J.E.; del Real-Olvera, J.; López-López, A. Performance of an upflow anaerobic filter in the treatment of cold meat industry wastewater. Process Saf. Environ. Prot. 2016, 102, 385-391. [CrossRef]

3. Thirugnanasambandham, K.; Sivakumar, V.; Maran, J.P. Response surface modelling and optimization of treatment of meat industry wastewater using electrochemical treatment method. J. Taiwan Inst. Chem. Eng. 2015, 46, 160-167. [CrossRef]

4. Barrera-Díaz, C.; Bilyeu, B.; Roa, G.; Bernal-Martinez, L. Physicochemical Aspects of Electrocoagulation. Sep. Purif. Rev. 2011, 40, 1-24. [CrossRef]

5. Sillanpää, M.; Shestakova, M. Chapter 2-Electrochemical Water Treatment Methods. In Electrochemical Water Treatment Methods; Sillanpää, M., Shestakova, M., Eds.; Butterworth-Heinemann: Oxford, UK, 2017; pp. 47-130.

6. Yasri, N.G.; Gunasekaran, S. Electrochemical Technologies for Environmental Remediation. In Enhancing Cleanup of Environmental Pollutants: Volume 2: Non-Biological Approaches; Anjum, N., Gill, S.S., Tuteja, N., Eds.; Springer International Publishing: Cham, Switzerland, 2017; pp. 5-73.

7. Wang, J.; Shih, Y.; Wang, P.Y.; Yu, Y.H.; Su, J.F.; Huang, C.-P. Hazardous waste treatment technologies. Water Environ. Res. 2019, 91, 1177-1198. [CrossRef] [PubMed]

8. Singh, S.; Srivastava, V.C.; Mall, I.D. Electrochemical Treatment of Dye Bearing Effluent with Different Anode-Cathode Combinations: Mechanistic Study and Sludge Analysis. Ind. Eng. Chem. Res. 2014, 53, 10743-10752. [CrossRef]

9. Ghazouani, M.; Akrout, H.; Jellali, S.; Bousselmi, L. Comparative study of electrochemical hybrid systems for the treatment of real wastewaters from agri-food activities. Sci. Total Environ. 2019, 647, 1651-1664. [CrossRef] [PubMed]

10. Tirado, L.; Gökkuş, Ö.; Brillas, E.; Sirés, I. Treatment of cheese whey wastewater by combined electrochemical processes. J. Appl. Electrochem. 2018, 48, 1307-1319. [CrossRef]

11. Tolgayılmaz, M.; Bayar, S.; Özcan, S. Treatment of sugar industry wastewater by electrocoagulation using Fe and Al electrodes: A comparative study. Desalin. Water Treat. 2018, 131, 206-211. [CrossRef]

12. Cañizares, P.; Carmona, M.; Lobato, J.; Martínez, F.; Rodrigo, M.A. Electrodissolution of Aluminum Electrodes in Electrocoagulation Processes. Ind. Eng. Chem. Res. 2005, 44, 4178-4185. [CrossRef]

13. Sahu, O.; Mazumdar, B.; Chaudhari, P.K. Treatment of wastewater by electrocoagulation: A review. Environ. Sci. Pollut. Res. Int. 2014, 21, 2397-2413. [CrossRef]

14. Reed, R.; MarksII, R.J. Neural Smithing: Supervised Learning in Feedforward Artificial Neural Networks; MIT Press: Cambridge, MA, USA, 1999.

15. Sebti, A.; Boutra, B.; Trari, M.; Aoudjit, L.; Igoud, S. Application of Artificial Neural Network for Modeling Wastewater Treatment Process. In Smart Energy Empowerment in Smart and Resilient Cities; Springer International Publishing: Cham, Switzerland, 2020.

16. Valente, G.F.S.; Mendonca, R.C.S.; Pereira, J.A.M.; Felix, L.B. Artificial neural network prediction of chemical oxygen demand in dairy industry effluent treated by electrocoagulation. Sep. Purif. Technol. 2014, 132, 627-633. [CrossRef]

17. Morales-Rivera, J.; Sulbarán-Rangel, B.; Gurubel-Tun, K.J.; del Real-Olvera, J.; Zúñiga-Grajeda, V. Modeling and Optimization of COD Removal from Cold Meat Industry Wastewater by Electrocoagulation Using Computational Techniques. Processes 2020, 8, 1139. [CrossRef]

18. Nasr, M.; Ateia, M.; Hassan, K. Artificial intelligence for greywater treatment using electrocoagulation process. Sep. Sci. Technol. 2016, 51, 96-105. [CrossRef]

19. Besharati Fard, M.; Mirbagheri, S.A.; Pendashteh, A.; Alavi, J. Biological treatment of slaughterhouse wastewater: Kinetic modeling and prediction of effluent. J. Environ. Health Sci. Eng. 2019, 17, 731-741. [CrossRef] [PubMed] 
20. Gadekar, M.R.; Ahammed, M.M. Modelling dye removal by adsorption onto water treatment residuals using combined response surface methodology-artificial neural network approach. J. Environ. Manag. 2019, 231, 241-248. [CrossRef]

21. Aber, S.; Amani-Ghadim, A.R.; Mirzajani, V. Removal of Cr(VI) from polluted solutions by electrocoagulation: Modeling of experimental results using artificial neural network. J. Hazard. Mater. 2009, 171, 484-490. [CrossRef]

22. Thirugnanasambandham, K.; Shine, K. Investigation on the Removal of Chromium from Wastewater using Electrocoagulation. Int. J. Chem. React. Eng. 2018, 16. [CrossRef]

23. Hasani, G.; Daraei, H.; Shahmoradi, B.; Gharibi, F.; Maleki, A.; Yetilmezsoy, K.; McKay, G. A novel ANN approach for modeling of alternating pulse current electrocoagulation-flotation (APC-ECF) process: Humic acid removal from aqueous media. Process Saf. Environ. Prot. 2018, 117, 111-124. [CrossRef]

24. Peralta-Hernández, J.M.; Picos, A. Genetic algorithm and artificial neural network model for prediction of discoloration dye from an electro-oxidation process in a press-type reactor. Water Sci. Technol. 2018, 78, 925-935. [CrossRef]

25. Da Silva Ribeiro, T.; Grossi, C.D.; Merma, A.G.; Santos, B.F.D.; Torem, M.L. Removal of boron from mining wastewaters by electrocoagulation method: Modelling experimental data using artificial neural networks. Miner. Eng. 2019, 131, 8-13. [CrossRef]

26. David, C.; Thangavelu, A. Degradation of distillery effluent by twisted-type Iron electrodes: Experimental with ANN approach. Int. J. Environ. Anal. Chem. 2020, 1-13. [CrossRef]

27. Kuokkanen, V.; Kuokkanen, T.; Rämö, J.; Lassi, U. Recent Applications of Electrocoagulation in Treatment of Water and Wastewater-A Review. Green Sustain. Chem. 2013, 3, 89-121. [CrossRef]

28. Baird, R.; Bridgewater, L. Standard Methods for the Examination of Water and Wastewater; American Public Health Association: Washington, DC, USA, 2017.

29. Kaur, P.; Sangal, V.K.; Kushwaha, J.P. Modeling and evaluation of electro-oxidation of dye wastewater using artificial neural networks. RSC Adv. 2015, 5, 34663-34671. [CrossRef]

30. Mirsoleimani-azizi, S.M.; Amooey, A.A.; Ghasemi, S.; Salkhordeh-panbechouleh, S. Modeling the Removal of Endosulfan from Aqueous Solution by Electrocoagulation Process Using Artificial Neural Network (ANN). Ind. Eng. Chem. Res. 2015, 54, 9844-9849. [CrossRef]

31. Betiku, E.; Odude, V.O.; Ishola, N.B.; Bamimore, A.; Osunleke, A.S.; Okeleye, A.A. Predictive capability evaluation of RSM, ANFIS and ANN: A case of reduction of high free fatty acid of palm kernel oil via esterification process. Energy Convers. Manag. 2016, 219-230. [CrossRef]

32. Tahreen, A.; Jami, M.S.; Ali, F. Role of electrocoagulation in wastewater treatment: A developmental review. J. Water Process Eng. 2020, 37, 101440. [CrossRef]

33. Al-Qodah, Z.; Tawalbeh, M.; Al-Shannag, M.; Al-Anber, Z.; Bani-Melhem, K. Combined electrocoagulation processes as a novel approach for enhanced pollutants removal: A state-of-the-art review. Sci. Total Environ. 2020, 744, 140806. [CrossRef]

34. Bekkari, N.; Zeddouri, A. Using artificial neural network for predicting and controlling the effluent chemical oxygen demand in wastewater treatment plant. Manag. Environ. Qual. Int. J. 2019, 30, 593-608. [CrossRef]

Publisher's Note: MDPI stays neutral with regard to jurisdictional claims in published maps and institutional affiliations.

(C) 2020 by the authors. Licensee MDPI, Basel, Switzerland. This article is an open access article distributed under the terms and conditions of the Creative Commons Attribution (CC BY) license (http://creativecommons.org/licenses/by/4.0/). 